\title{
Molecular design, chemical synthesis, and biological evaluation of anthracene-carbohydrate hybrids as novel DNA photocleaving and photoselective cytotoxic agents
}

\author{
Kazunobu Toshima,* Masashi Hasegawa, Junji Shimizu, and Shuichi Matsumura \\ Department of Applied Chemistry, Faculty of Science and Technology, Keio University, \\ 3-14-1 Hiyoshi, Kohoku-ku, Yokohama 223-8522, Japan \\ E-mail: toshima@applc.keio.ac.jp
}

\section{Dedicated to Professor Karsten Krohn on the occasion of his $60^{\text {th }}$ birthday}

(received 30 Mar 04; accepted 18 Aug 04; published on the web 23 Aug 04)

\begin{abstract}
The anthracene-carbohydrate hybrids were designed and synthesized via an effective glycosidation. The hybrids cleaved double stranded DNA at the guanine site upon irradiation with UV light of a long wavelength and without any additive. The anthracene-carbohydrate hybrid system was very effective for the DNA cleavage. Furthermore, the anthracenecarbohydrate hybrids exhibited photoselective and strong cytotoxicity against cancer cells with photoirradiation.
\end{abstract}

Keywords: Anthracene, carbohydrate, DNA cleavage, cytotoxicity, photoirradiation

\section{Introduction}

The studies of the interaction between small molecules and DNA, especially the effects of the structural characteristics of the small molecules on the DNA interaction, are very important for the design of new DNA targeting antitumor drugs. ${ }^{1}$ In this context, the development of photochemical DNA cleaving agents, which selectively cleave DNA by irradiation with light of a specific wavelength under mild conditions and without any additives, such as metals and reducing agents, is very interesting from chemical and biological standpoints and offers considerable potential in medicine, especially in the post-genome era. ${ }^{2}$ Furthermore, photodynamic therapy using a photosensitizing drug has recently emerged as a promising modality against cancer and allied diseases. ${ }^{3}$ In this paper, we report the molecular design, chemical synthesis, DNA photocleaving property and cytotoxicity of such novel and artificial light activatable DNA cleaving and cytotoxic agents, that include the anthracene-carbohydrate hybrids. 


\section{Results and Discussion}

In our first approach to create such novel DNA photocleaving molecules, we noted anthracene, because anthracene possesses an electron rich and planar structure, which is suitable as a DNA intercalator. Furthermore, anthracene is known to generate a photo-excited state by photoirradiation. ${ }^{4}$ Therefore, we expected that the photo-excited species coming from anthracene would be capable of cleaving DNA. To confirm our hypothesis, we first examined the photoinduced DNA cleaving activities of anthracene $\mathbf{1}$ and its derivative $\mathbf{2}$ along with a naphthalene derivative 3 (Figure 1) using supercoiled $\Phi$ X174 DNA (Form I). As is evident from Figure 1, the anthracene derivatives $1(100 \mu \mathrm{M})$ and $2(100 \mu \mathrm{M})$ caused a weak single-strand scission of DNA by photoirradiation using long wavelength UV light $(365 \mathrm{~nm})$ without any further additives, leading to the nicked open circular DNA (Form II) (lanes 4 in (a) and (b) in Figure 1). On the other hand, the naphthalene derivative 3 showed no DNA cleaving activity under similar conditions (lane 4 in (c) in Figure 1).<smiles>c1ccc2cc3ccccc3cc2c1</smiles>

1<smiles>OCc1ccc2cc3ccccc3cc2c1</smiles>

2<smiles>OCc1ccc2ccccc2c1</smiles>

3 (a)

\section{Form I Form III Form II}

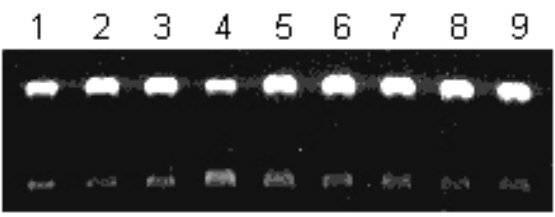

(b)

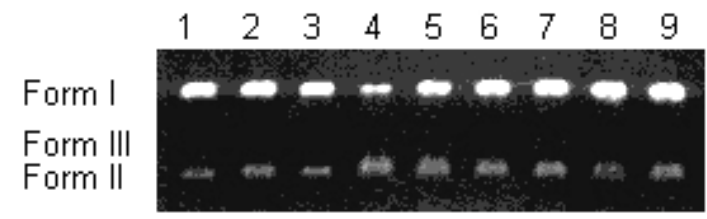

(c)

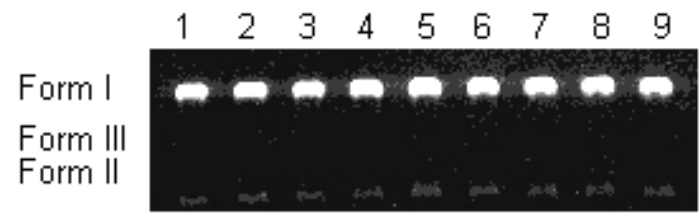

Figure 1. Photocleavage of supercoiled $\Phi X 174$ DNA. $\Phi X 174$ DNA (50 $\mu \mathrm{M}$ per base pair) was incubated with various compounds in $20 \%$ acetonitrile in Tris- $\mathrm{HCl}$ buffer $(\mathrm{pH} 7.5,50 \mathrm{mM})$ at $25^{\circ} \mathrm{C}$ for $2 \mathrm{~h}$ under irradiation of the UV lamp $(365 \mathrm{~nm}, 15 \mathrm{~W})$ placed at $10 \mathrm{~cm}$ from the mixture, and analyzed by gel electrophoresis (0.9\% agarose gel, ethidium bromide stain): (a), (b) and (c) for the compounds 1, 2 and 3, respectively: lane 1, DNA alone; lane 2, DNA with UV; lane 3, DNA+compound $(100 \mu \mathrm{M})$ without UV; lanes 4-9, compound $(100,30,10,3,1$, and $0.3 \mu \mathrm{M}$, respectively) following UV irradiation. Form I: covalently closed supercoiled DNA, Form II: open circular DNA, and Form III: linear DNA. 
It was also confirmed that in the absence of light no DNA cleavage by $\mathbf{1}$ and $\mathbf{2}$ was observed (lanes 3 in (a) and (b) in Figure 1). Thus, UV light functioned as a trigger to initiate these anthracene derivatives to produce the DNA strand scission. These results clearly demonstrate, for the first time, that anthracene derivatives are able to cleave DNA upon irradiation with long wavelength UV light without any additive and that the aromatic rings system of anthracene is essential for the DNA cleavage.

To further improve the DNA cleaving ability of the anthracene derivatives, we designed the anthracene-carbohydrate hybrids 4 and 5 (Scheme 1), because we have previously demonstrated that a suitably deoxygenated amino sugar showed a high affinity to DNA and significantly enhanced the intercalating ability of certain intercalators. ${ }^{5}$ The syntheses of the anomeric anthracene-carbohydrate hybrids $\mathbf{4}$ and $\mathbf{5}$ are summarized in Scheme 1. The glycosidation of the known 1-OAc sugar $\mathbf{6}^{5 \mathrm{e}}$ and the commercially available anthracene derivative 7 using TMSOTf in THF smoothly proceeded to afford the $\alpha$-glycoside $\mathbf{8}$ and its $\beta$-anomer $\mathbf{9}$ in a ratio of 1.2:1. The deprotection of the acetyl groups of $\mathbf{8}$ and 9 employing $\mathrm{NaOMe}$ in $\mathrm{MeOH}-\mathrm{CHCl}_{3}$ yielded the desired anthracene-carbohydrate hybrids 4 and 5, respectively.

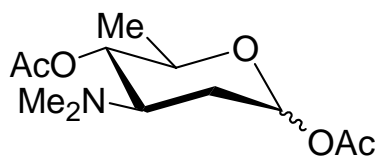

6
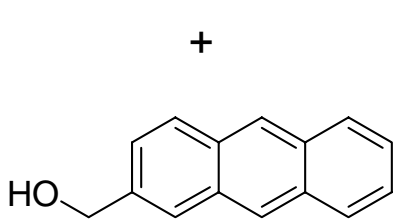

7

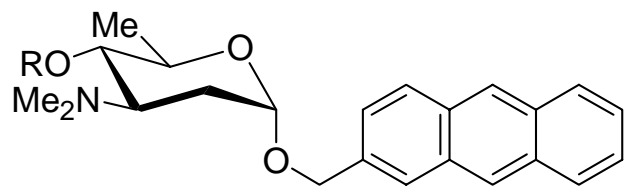

8, $\mathrm{R}=\mathrm{Ac} \stackrel{\mathrm{b}}{\longrightarrow} 4, \mathrm{R}=\mathrm{H}$

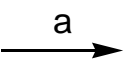

$+$

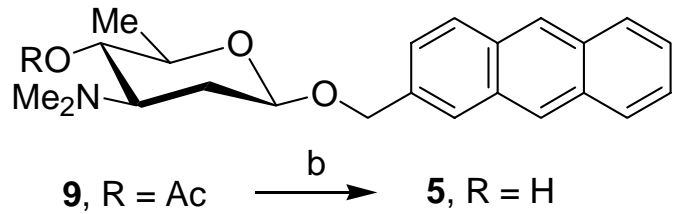

Scheme 1. Synthesis of anthracene-carbohydrate hybrids 4 and 5.

Reagents and conditions: (a) TMSOTf, THF, $0{ }^{\circ} \mathrm{C}$, $30 \mathrm{~min}$, affording 8 (44\%) and 9 (37\%); (b) $\mathrm{NaOMe}, \mathrm{CHCl}_{3}-\mathrm{MeOH}, 25^{\circ} \mathrm{C}, 6 \mathrm{~h}$, yielding $4(84 \%), 5(62 \%)$.

With the designed anthracene-carbohydrate hybrids $\mathbf{4}$ and $\mathbf{5}$ in hand, the photo-induced DNA cleaving activities of these hybrids along with the sugar derivative $\mathbf{1 0}$ were next assayed using supercoiled $\Phi X 174$ DNA in concentrations of 100-0.3 $\mu \mathrm{M}$. Based on the results shown in Figure 3, the anthracene-carbohydrate hybrids 4 and 5 caused effective DNA cleavage during irradiation using a long wavelength UV light. It was confirmed that the DNA cleaving abilities of the anthracene-carbohydrate hybrids $\mathbf{4}$ and $\mathbf{5}$ were found to be much stronger than those of $\mathbf{1}$ and 2. Furthermore, it was found that the $\alpha$-anomer 4 had a higher DNA cleaving ability than the $\beta$ anomer 5 [(a) and (b) in Figure 2]. Thus, the DNA cleaving activity was dependent on the 
configuration of the glycosidic bond of the sugar moiety in the hybrids. On the other hand, the carbohydrate 10 had no DNA cleaving ability under similar conditions (c) in Figure 2). These results strongly suggest that the suitably deoxygenated amino sugar in these hybrids works well as the DNA groove binder and significantly enhances the intercalating ability of the anthracene. The DNA cleaving site specificity of the anthracene derivatives 1, 2, 4 and 5 was analyzed next according to the Sanger protocol. ${ }^{6}$ Since the Sanger sequencing reactions result in base incorporation, cleavage at the nucleotide $\mathrm{N}$ (sequencing) represents a cleaving site by the agent or the Maxam-Gilbert reaction at $\mathrm{N}+1 .^{7}$

4

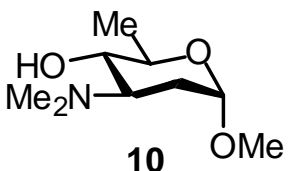

(a)

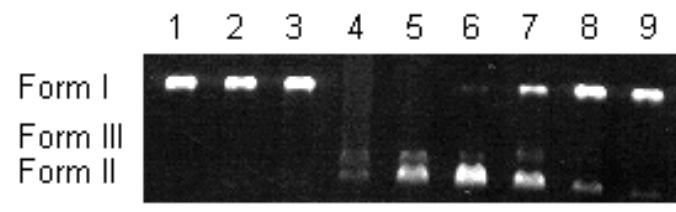

(b)

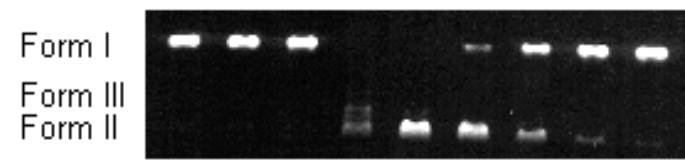

(c)

Form I

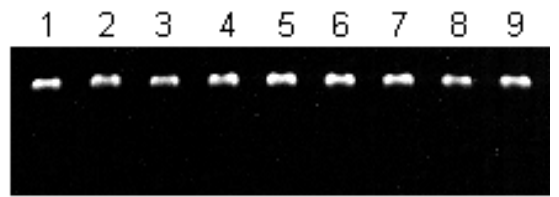

Figure 2. Photocleavage of supercoiled $\Phi$ X174 DNA. ФX174 DNA (50 $\mu \mathrm{M}$ per base pair) was incubated with various compounds in $20 \%$ acetonitrile in Tris- $\mathrm{HCl}$ buffer $(\mathrm{pH} 7.5,50 \mathrm{mM})$ at $25^{\circ} \mathrm{C}$ for $2 \mathrm{~h}$ under irradiation of the UV lamp $(365 \mathrm{~nm}, 15 \mathrm{~W})$ placed at $10 \mathrm{~cm}$ from the mixture, and analyzed by gel electrophoresis ( $0.9 \%$ agarose gel, ethidium bromide stain): (a), (b) and (c) for the compounds 4, 5 and 10, respectively: lane 1, DNA alone; lane 2, DNA with UV; lane 3, DNA+compound $(100 \mu \mathrm{M})$ without UV; lanes 4-9, compound (100, 30, 10, 3, 1, and 0.3 $\mu \mathrm{M}$, respectively) following UV irradiation. Form I: covalently closed supercoiled DNA, Form II: open circular DNA, and Form III: linear DNA.

The results shown in Figure 3 clearly indicate that all the anthracene derivatives selectively cleaved DNA at the guanine sites and the site-selective DNA cleavage was enhanced upon treatment with hot piperidine. Since both the free radical and singlet oxygen scavengers, dimethyl sulfoxide and 2,2,6,6-tetramethylpiperidine, inhibited the DNA cleavage, it is very likely that the oxidation by $\bullet \mathrm{OH}$ and ${ }^{1} \mathrm{O}_{2}$ is the initial step for the photo-induced destruction of the guanine bases. ${ }^{2}$ 


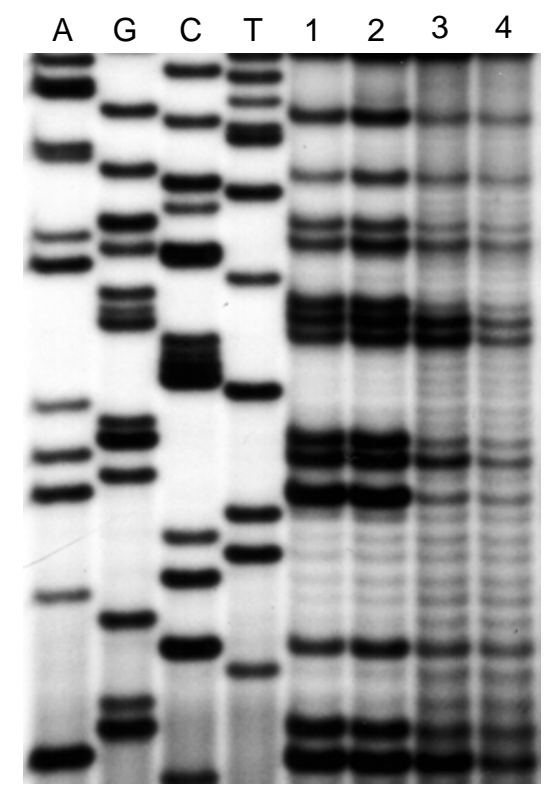

Figure 3. Autoradiogram of $12 \%$ polyacrylamide- $8 \mathrm{M}$ urea slab gel electrophoresis for sequence analysis. The 5'-end-labeled M13mp18 DNA at the primer site was cleaved by the compound at $\mathrm{pH} 7.5$ and $25^{\circ} \mathrm{C}$ for $1 \mathrm{~h}$ under irradiation of the UV lamp $(365 \mathrm{~nm}, 15 \mathrm{~W})$ placed at $10 \mathrm{~cm}$ from the mixture: lanes A, G, C and T; Sanger A, G, C and T reactions, respectively; lanes 1, 2, 3 and 4; the compounds 4, 5, 1 and $2(30 \mu \mathrm{M})$, respectively, following UV irradiation: DNAs for lanes $1 \sim 4$ were treated with hot piperidine prior to gel electrophoresis.

With the favorable results for the interactive and photocleaving ability of the anthracenecarbohydrate hybrids against the naked DNA, the cytotoxicities of the hybrids $\mathbf{4}$ and $\mathbf{5}$ were next examined using HeLa S3 cancer cells exposed to each agent for $72 \mathrm{~h}$ with or without $1 \mathrm{~h}$ of photoirradiation. ${ }^{8}$ The $\mathrm{IC}_{50}$ values of $\mathbf{4}$ and $\mathbf{5}$ aginst the HeLa S3 cells without photoirradiation were 6.3 and $19 \mu \mathrm{M}$, respectively, while those with photoirradiation were 0.19 and $0.055 \mu \mathrm{M}$, respectively. These results indicate that the cytotoxicities of the anthracene-carbohydrate hybrids 4 and 5 with photoirradiation are much higher than those without photoirradiation. Furthermore, these results also demonstrate that the DNA-cleaving activity induced by photoirradiation significantly affects the cytotoxicity of the hybrids, and the life of cancer cells can be controlled by treatment with an appropriate amount of the anthracene-carbohydrate hybrid with or without photoirradiation.

\section{Conclusions}

We demonstrated not only the molecular design and chemical synthesis of novel anthracenecarbohydrate hybrids, but also their DNA photocleavage and cytotoxic profiles. The described chemistry and biological evaluation provided significant information about the molecular design of novel and selective DNA photocleaving and cytotoxic agents. 


\section{Experimental Section}

General Procedures. Melting points were determined on a micro hot-stage Yanako MP-S3. Optical rotations were measured on a JASCO DIP-360 photoelectric polarimeter in chloroform unless otherwise noted. ${ }^{1} \mathrm{H}-\mathrm{NMR}$ spectra were recorded on a Lambda $300(300 \mathrm{MHz})$ in $\mathrm{CDCl}_{3}$ using TMS as internal standard unless otherwise noted. Silica gel TLC and column chromatography were performed on Merck TLC 60F-254 (0.25 mm) and Kanto Chemical Co., Inc Silica Gel 60 N (spherical, neutral), respectively. Air- and/or moisture-sensitive reactions were carried out under an atmosphere of argon with oven-dried glassware. In general, organic solvents were purified and dried by the appropriate procedure, and evaporation and concentration were carried out under reduced pressure below $30^{\circ} \mathrm{C}$, unless otherwise noted.

2-Anthrylmethyl 3- $N, N^{\prime}$-dimethylamino-2,3,6-trideoxy- $\alpha$-D-arabino-hexopyranoside (4). To a stirred mixture of 6 (135 $\mathrm{mg}, 0.522 \mathrm{mmol}), 7(130 \mathrm{mg}, 0.626 \mathrm{mmol})$ and MS 4A (95 $\mathrm{mg})$ in dry THF $(5.2 \mathrm{~mL})$ was added TMSOTf $(0.236 \mathrm{~mL}, 1.31 \mathrm{mmol})$ at $0{ }^{\circ} \mathrm{C}$. The reaction mixture was stirred at $0{ }^{\circ} \mathrm{C}$ for $30 \mathrm{~min}$ and poured into ice-cold saturated $\mathrm{NaHCO}_{3}$ aq. The resultant mixture was extracted with $\mathrm{CHCl}_{3}$ and the extracts were washed with brine, dried over anhydrous $\mathrm{Na}_{2} \mathrm{SO}_{4}$ and concentrated in vacuo. Purification of the residue by column chromatography $(60 \mathrm{~g}$ of silica gel, $1 / 10 n$-hexane/EtOAc) gave the $\alpha$-anomer $8(94.0 \mathrm{mg}, 44 \%)$ and $\beta$-anomer 9 (78.3 mg, 37\%) as white solids. To a stirred solution of $8(64.5 \mathrm{mg}, 0.158 \mathrm{mmol})$ in dry $\mathrm{CHCl}_{3}$ $\mathrm{MeOH}(1 / 1,1.9 \mathrm{~mL})$ was added $5 \mathrm{~N} \mathrm{NaOMe}(0.095 \mathrm{~mL}, 0.475 \mathrm{mmol})$ at $0{ }^{\circ} \mathrm{C}$. After stirring at $25^{\circ} \mathrm{C}$ for $6 \mathrm{~h}$, the reaction mixture was neutralized with dryice and then poured into water. The resultant mixture was extracted with $\mathrm{CHCl}_{3}$ and the extracts were washed with brine, dried over anhydrous $\mathrm{Na}_{2} \mathrm{SO}_{4}$ and concentrated in vacuo. Purification of the residue by column chromatography (20 g of silica gel, $\left.1 / 3 \mathrm{CHCl}_{3} / \mathrm{MeOH}\right)$ gave $4(48.6 \mathrm{mg}, 84 \%)$ as white solids. $R_{f}$ $0.24\left(1 / 3 \mathrm{CHCl}_{3} / \mathrm{MeOH}\right) ;[\alpha]^{28}{ }_{\mathrm{D}}+19.9^{\circ}\left(c \mathrm{c} 0.33, \mathrm{CHCl}_{3}\right), \mathrm{mp} 186.0-187.0{ }^{\circ} \mathrm{C} .{ }^{1} \mathrm{H}-\mathrm{NMR}(300 \mathrm{MHz}$, $\left.\mathrm{CDCl}_{3}\right): \delta 1.34(3 \mathrm{H}, \mathrm{d}, J=6.0 \mathrm{~Hz}), 1.66(1 \mathrm{H}, \mathrm{ddd}, J=12.8,12.8$ and $4.0 \mathrm{~Hz}), 1.94(1 \mathrm{H}, \mathrm{ddd}, J=$ 12.8, 4.0 and $1.0 \mathrm{~Hz}), 2.30(6 \mathrm{H}, \mathrm{s}), 3.02(1 \mathrm{H}, \mathrm{ddd}, J=12.8,9.8$ and $4.0 \mathrm{~Hz}), 3.17(1 \mathrm{H}, \mathrm{dd}, J=$ 9.8 and $9.8 \mathrm{~Hz}), 3.83(1 \mathrm{H}, \mathrm{dq}, J=9.8$ and $6.0 \mathrm{~Hz}), 4.64$ and 4.88 (each $2 \mathrm{H}, \mathrm{ABq}, J=13.0 \mathrm{~Hz}$ ), $5.10(1 \mathrm{H}, \mathrm{dd}, J=4.0$ and $1.0 \mathrm{~Hz}), 7.42-7.50(3 \mathrm{H}, \mathrm{m}), 7.92-8.04(4 \mathrm{H}, \mathrm{m}), 8.41(2 \mathrm{H}, \mathrm{s})$. Anal. Calcd for $\mathrm{C}_{23} \mathrm{H}_{27} \mathrm{NO}_{3}$ : C, 75.59; H, 7.45; N, 3.83. Found: C, 75.30; H, 7.36; N, 3.66.

2-Anthrylmethyl 3- $N, N^{\prime}$-dimethylamino-2,3,6-trideoxy- $\beta$-D-arabino-hexopyranoside (5). To a stirred solution of $9(61.6 \mathrm{mg}, 0.150 \mathrm{mmol})$ in dry $\mathrm{CHCl}_{3} / \mathrm{MeOH}(1: 1,1.2 \mathrm{~mL})$ was added $5 \mathrm{~N}$ $\mathrm{NaOMe}(0.090 \mathrm{~mL}, 0.451 \mathrm{mmol})$ at $0{ }^{\circ} \mathrm{C}$. After stirring at $25^{\circ} \mathrm{C}$ for $6 \mathrm{~h}$, the reaction mixture was neutralized with dryice and then poured into water. The resultant mixture was extracted with $\mathrm{CHCl}_{3}$ and the extracts were washed with brine, dried over anhydrous $\mathrm{Na}_{2} \mathrm{SO}_{4}$ and concentrated in vacuo. Purification of the residue by column chromatography (15 g of silica gel, $\left.\mathrm{CHCl}_{3} / \mathrm{MeOH} 1: 3\right)$ gave $4(34.0 \mathrm{mg}, 62 \%)$ as white solids. Rf $0.44\left(\mathrm{CHCl}_{3} / \mathrm{MeOH} 1: 3\right)$; $[\alpha]_{D}^{28}-15.8^{\circ}\left(c\right.$ 0.21, $\left.\mathrm{CHCl}_{3}\right), \mathrm{mp} 209.0-210.0{ }^{\circ} \mathrm{C} ;{ }^{1} \mathrm{H}-\mathrm{NMR}\left(300 \mathrm{MHz}, \mathrm{CDCl}_{3}\right): \delta 1.44(3 \mathrm{H}, \mathrm{d}, \mathrm{J}$ $=6.0 \mathrm{~Hz}), 1.60(1 \mathrm{H}, \mathrm{ddd}, J=12.8,12.8$ and $10.0 \mathrm{~Hz}), 2.05(1 \mathrm{H}$, ddd, $J=12.8,4.0$ and $2.0 \mathrm{~Hz})$, 
$2.27(6 \mathrm{H}, \mathrm{s}), 2.45(1 \mathrm{H}$, ddd, $J=12.8,9.8$ and $4.0 \mathrm{~Hz}), 3.11(1 \mathrm{H}, \mathrm{dd}, J=9.8$ and $9.8 \mathrm{~Hz}), 3.34$ $(1 \mathrm{H}, \mathrm{dq}, J=9.8$ and $6.0 \mathrm{~Hz}), 4.64(1 \mathrm{H}, \mathrm{dd}, J=9.8$ and $2.0 \mathrm{~Hz}), 4.79$ and 5.10 (each $2 \mathrm{H}, \mathrm{ABq}, J=$ $13.0 \mathrm{~Hz}), 7.43-7.50(3 \mathrm{H}, \mathrm{m}), 7.93-8.04(4 \mathrm{H}, \mathrm{m}), 8.40(2 \mathrm{H}, \mathrm{s})$. Anal. Calcd for $\mathrm{C}_{23} \mathrm{H}_{27} \mathrm{NO}_{3}$ : C, 75.59; H, 7.45; N, 3.83. Found: C, 75.41; H, 7.38; N, 3.65.

\section{DNA Cleavage studies}

ФX174 DNA and M13mp18 ss DNA were purchased from Nippon Gene Co., Ltd., and TaKaRa Bio Inc., respectively. XX-15 BLB (UVP Inc.) was used as a UV lamp (365 nm, 15 or $30 \mathrm{~W}$ ) for photoirradiation.

Assay for damage to DNA. All the DNA cleavage experiments were performed with ФX174 DNA ( $50 \mu \mathrm{M} /$ base pair) in a volume of $6 \mu \mathrm{L}$ containing $20 \%$ acetonitrile in $50 \mathrm{mM}$ Tris- $\mathrm{HCl}$ buffer ( $\mathrm{pH} \mathrm{7.5)}$ at $25^{\circ} \mathrm{C}$ for $2 \mathrm{~h}$ under irradiation of the UV lamp (365 nm, $\left.15 \mathrm{~W}\right)$ placed $10 \mathrm{~cm}$ from the mixture. The DNA-sample levels were varied as indicated in the figure captions. The results were analyzed using $0.9 \%$ agarose gel electrophoresis and detection with ethidium bromide fluorescence. The electrophoresis gels were immediately visualized on a UV transilluminator and photographed using black and white instant film. Figures 1 and 2 show the pictures of the agarose gel electrophoresis results.

Identification of DNA cleavage sites. The reaction samples contained the compounds $(30 \mu \mathrm{M})$ and the 5'-end-labelled M13mp18 DNA (40 ng) in a volume of $30 \mu \mathrm{L}$ containing $20 \%$ acetonitrile in TE buffer (10 mM Tris-HCl, $1 \mathrm{mM}$ EDTA, $\mathrm{pH}$ 8.5). The cleavage reactions were allowed to proceed under the same conditions described above. To stop the reactions, each reaction sample was washed with a solution of TE buffer-saturated phenol-chloroform-isoamyl alcohol (25:24:1) and the resulting aqueous layer was lyophilized. After each lyophilized sample was dissolved in $1 \mathrm{M}$ piperidine-water $(20 \mu \mathrm{L})$ and then heated at $90{ }^{\circ} \mathrm{C}$ for $30 \mathrm{~min}$, each sample was again lyophilized. Each lyophilized sample was dissolved in a loading buffer containing distilled water, 95\% deionized formamide, $10 \mathrm{mM}$ EDTA, $0.05 \%$ xylene cyanole FF, and $0.05 \%$ bromophenol blue and then the mixture was loaded onto a $12 \%$ polyacrylamide gel containing 8 $\mathrm{M}$ urea in TBE buffer. DNA sequencing was carried out by the Sanger method. Figure 4 shows a picture of the autoradiogram.

\section{Cytotoxicity assay}

The cells were treated with each compound at the concentrations of $100,30,10,3,1,0.3,0.1$, 0.03 and $0.01 \mu \mathrm{M}$ with photoirradiation at $25^{\circ} \mathrm{C}$ for $1 \mathrm{~h}$ with a UV lamp (365 nm, $\left.30 \mathrm{~W}\right)$ placed

$25 \mathrm{~cm}$ from the mixture, and incubated for $72 \mathrm{~h}$ at $37{ }^{\circ} \mathrm{C}$. The cell viability was determined using the XTT-tetrazolium assay described by Scudiero. ${ }^{8}$ 


\section{Acknowledgements}

This research was partially supported by Grant-in-Aid for the 21st Century COE program "KEIO Life Conjugate Chemistry" and for General Scientific Research from the Ministry of Education, Culture, Sports, Science, and Technology, Japan.

\section{References}

1. Demeunynck, M.; Bailly, C.; Wilson, W. D. DNA and RNA Binders; Wiley-VCH: Weinheim, 2003.

2. Armitage, B. Chem. Rev. 1998, 98, 1171.

3. (a) Brown, J. E.; Brown, S. B.; Vernon, D. I. J. Soc. Dyers Colour. 1999, 115, 249. (b) Morgan, A. R. Curr. Med. Chem. 1995, 2, 604. (c) Bonnett, R. Chem. Soc. Rev. 1995, 19. (d) Henderson, R. W.; Dougherty, T. J. Photodynamic Therapy: Basic Principles and Clinical Applications; Marcel Dekker: New York, 1992.

4. Sigman, M. E.; Zingg, S. P.; Pagni, R. M.; Burns, J. H. Tetrahedron Lett. 1991, 32, 5737.

5. (a) Toshima, K.; Ouchi, H.; Okazaki, Y.; Kano, T.; Moriguchi, M.; Asai, A.; Matsumura, S. Angew. Chem., Int. Ed. 1997, 36, 2748. (b) Toshima, K.; Takano, R.; Maeda, Y.; Suzuki, M.; Asai, A.; Matsumura, S. Angew. Chem. Int. Ed. 1999, 38, 3733. (c) Toshima, K.; Maeda, Y.; Ouchi, H.; Asai, A.; Matsumura, S. Bioorg. Med. Chem. Lett. 2000, 10, 2163. (d) Toshima, K.; Takai, S.; Maeda, Y.; Takano, R.; Matsumura, S. Angew. Chem., Int. Ed. 2000, 39, 3656. (e) Toshima, K.; Okuno, Y.; Nakajima, Y.; Matsumura, S. Bioorg. Med. Chem. Lett. 2002, 12, 671. (f) Toshima, K.; Takano, R.; Ozawa, T.; Matsumura, S. Chem. Commun. 2002, 212.

6. Sanger, F.; Nicklen, S.; Coulson, A. R. Proc. Natl. Acad. Sci. USA 1977, 74, 5463.

7. (a) Boger, D. L.; Munk, S. A.; Zarrinmayeh, H.; Ishizaki, T.; Haught, J.; Bina, M. Tetrahedron 1991, 47, 2661. (b) Toshima, K.; Ohta, K.; Ohashi, A.; Nakamura, T.; Nakata, M.; Tatsuta, K.; Matsumura, S. J. Am. Chem. Soc. 1995, 117, 4822.

8. Scudiero, D. A.; Shoemaker, R. H.; Paull, K. D.; Monks, A.; Tierney, S.; Nofziger, T. H.; Currens, M. J.; Seniff, D.; Boyd, M. R. Cancer Res. 1988, 48, 4827. 